\title{
POLA RELASI MANUSIA DALAM PONTOBANNANG TORAJA (Manner of Human Relationship Toraja Pontobannang)
}

\author{
Abd. Rasyid \\ Balai Bahasa Sulawesi Selatan \\ Jalan Sultan Alauddin Km 7, Talasalapang, Makassar \\ Telepon (0411) 882401, Faksimile (0411) 882403 \\ Diterima: 12 April 2018; Direvisi: 22 Juni 2018; Disetujui: 25 Juni 2018
}

\begin{abstract}
This research aims to obtain the manner pictures of human relatioships in TorajanPontobannang by utilizing of sociology theory by using sociocultural approach and descriptive qualitative method. The analysis shows that the relations phenomenon, among human God, human and human (either personally or socially human and nature, and human with themselves.
\end{abstract}

Keywords: manner of relations; sociocultural; Torajan Pontobannang

\begin{abstract}
Abstrak
Tulisan ini bertujuan memperoleh gambaran ragam relasi manusia dalam pontobannang Toraja dengan memanfaatkan teori sosiologi sastra dengan pendekatan sosiokultural serta menggunakan metode deskriptif kualitatif. Dari analisis di atas, tampak fenomena relasi manusia dengan Tuhan, manusia dengan manusia (baik sebagai pribadi maupun sebagai masyarakat), manusia dengan alam, dan manusia dengan dirinya sendiri.
\end{abstract}

Kata kunci: pola relasi; sosiokultural; Pontobannang Toraja

\section{PENDAHULUAN}

Segi sosial dan budaya masyarakat Toraja yang kompleks mengakibatkan pengenalan terhadap manusia Toraja tidak akan pernah lengkap dan selesai karena manusia Toraja itu sendiri senantiasa berubah dan berkembang sejalan dengan perubahan dan perkembangan zaman. Namun, hal itu tidaklah berarti bahwa manusia Toraja tidak dapat dikenali. Salah satu sarana untuk mengenal manusia Toraja yakni melalui karya-karya sastranya. Dalam tulisan ini, penulis mengangkat salah satu jenis sastra Toraja yang oleh masyarakatnya dikenal dengan sebutan pontobannang. Pontobannang dapat diidentikkan dengan ungkapan dalam bahasa Indonesia.

Ungkapan adalah salah satu hasil sastra lama yang masih hidup hingga saat ini yang didalamnya sarat dengan berbagai gambaran problematika kehidupan manusia. Sebagai produk sastra bahasa ungkapan cenderung baku dan beku, baik dari segi struktur maupun maknanya. Secara universal, unsur yang dimiliki oleh semua bahasa dengan bentuk-bentuk baku dan beku yang sering disebut unsur idiom. Unsur tersebut diwariskan secara turun-temurun dengan struktur dan makna yang sama meskipun sebagian makna ekspresi itu tidak cocok pada budaya masa tertentu. Misalnya, di dalam bahasa Indonesia ungkapan "sedikit-sedikit, lama-lama menjadi bukit" tidak berlaku lagi bagi perhitungan nilai ekonomi sekarang. Prinsip tersebut dianut manusia Indonesia zaman dahulu dalam menabung uang, tetapi manusia Indonesia zaman sekarang sudah beralih ke sistem kredit yang dapat dengan cepat memperoleh sesuatu dengan, dan dengan perhitungan bahwa nilai ekonomis uang itu pun lama kelamaan akan berkurang. Budaya modern sekarang ini 
menuntut prinsip cepat dalam meraih sesuatu, tidak lagi biar lambat asal selamat.

Sebelum membahas lebih lanjut tentang pola relasi manusia dalam ungkapan Toraja, terlebih dahulu disampaikan batasan makna relasi. Dalam Kamus Besar Bahasa Indonesia (2008) dijelaskan pengertian relasi adalah hubungan; perhubungan; pertalian. Namun, dalam tulisan ini yang dimaksud relasi adalah hubungan manusia Toraja dengan entitas-entitas lain, yang memunculkan ideologi, aksi, dan reaksi.

\section{KERANGKA TEORI}

Penelitian ini menggunakan teori Sosiologisastra. Teori ini diterapkan dengan pertimbangan bahwa sastra tidak hanya berkaitan dengan dunia pribadi sastrawan, tetapi juga berkaitan dengan dunia sosial, usaha manusia untuk berinteraksi dan menyesuaikan diri, dan sekaligus usahanya mengubah dunia yang lebih baik serta bermanfaat (Damono, 2000: 3). Pandangan lain beranggapan bahwa sastra bukan kenyataan, melainkan sastra selalu berdasarkan kenyataan sosial (Sumarjo, 1979: 30).

Dengan demikian, wujud kenyataan sosial berupa perilaku manusia yang verbal dan fisik dapat melahirkan kreasi dan variasi budaya, seperti seni musik, seni sastra, dan lain-lain. Oleh karena itu, penelitian ini menggunakan pendekatan sosiokultural. Fokus pendekatan adalah pengaruh karya sastra dan relasi kehidupan manusia Toraja. Fenomena yang melingkupi kehidupan manusia adalah persoalan-persoalan yang lahir karena adanya hubungan manusia dengan Tuhan, hubungan manusia dengan masyarakat, hubungan manusia dengan dirinya sendiri, hubungan manusia dengan manusia lain, dan hubungan manusia dengan alam. Hubungan manusia dengan Tuhan akan melahirkan karakter manusia yang religius, sementara hubungan manusia dengan masyarakat akan membentuk manusia yang berwatak sosial. Dapat pula timbul manusia yang tak religius dan tak sosial dalam hubungan manusia dengan Tuhan dan masyarakat, atau bahkan beberapa nuansa di antara manusia yang religius dan sosial serta manusia yang tak religius dan tak sosial.

Selain pendekatan tersebut, dimanfaatkan pula teori struktural bahasa. Teori ini digunakan sehubungan dengan penelitian deskriptif seperti yang dikemukakan oleh de Saussure (dalam Djajasudarma, 1997: 8) yang menyarankan pemerian unsur bahasa dengan pemahaman bahwa setiap unsur itu berhubungan satu sama lain dalam satu kesatuan yang terpadu.

\section{METODE}

Penelitian ini bersifat deskriptif kualitatif. Analisis beranjak dari batasan umum atau dedukasi kemudian dalam pemahaman makna menggunakan kajian induksi (Suwondo, 2003: 67). Teknik pengumpulan data digunakan teknik pustaka, klasifikasi data dilakukan dengan pembacaan aktif, kemudian hasilnya dicatat dan dideskripsikan.

\section{PEMBAHASAN}

Relasi manusia Toraja yang akan dikemukakan dalam pembahasan ini mencakup hubungan manusia dengan Tuhan, hubungan manusia dengan alam, hubungan dengan manusia dengan masyarakat, hubungan manusia dengan manusia lain, dan hubungan dengan diri sendiri. Pola relasi tersebut menggambarkan karakter manusia Toraja sebagai mahluk sosial, mahluk beragama, mahluk peduli lingkungan hidup, dan mahluk yang memperhatikan kondisi diri, baik yang berkaitan lahir maupun batin. Berikut ini diuraikan satu persatu.

\section{Hubungan Manusia dengan Tuhan}

Manusia pada dasarnya adalah homo religius atau makhluk beragama. Sebagai homo religius, manusia percaya ada kekuasaan yang tertinggi, yakni Tuhan yang menciptakan manusia dan jagat raya ini. Oleh sebab itu, manusia selalu berusaha mengagungkan dan memuji nama Tuhan melalui doa dan upacaraupacara ritual. 
Meskipun manusia adalah homo religius yang menyembah Tuhan yang satu, adanya bermacam-macam agama mengakibatkan konsep Tuhan di mata manusia tidak sama. Bagi umat Kristen, Tuhan adalah Allah Bapa yang terwujud dalam Trinitas, bagi umat Islam, Tuhan adalah Allah yang Mahakuasa. Adanya bermacam-macam agama itu tidak menghalangi upaya manusia untuk mendekatkan diri kepada Tuhan sebagai pusat kekuasaan tertinggi.

Konsep hubungan manusia dengan Tuhan dapat disimak dalam ungkapan Toraja sebagai berikut.

\section{Masaranian (Sande, 1994: 58)}

Artinya: Hal atau banyak Kristennya.

Maksudnya: Orang yang taat kepada Tuhan dan jujur.

Dari ungkapan tersebut tergambar manusia yang senantiasa mengingat Tuhan dan menjalankan perintah-perintah-Nya. Sebagai makhluk yang sadar akan keberadaannya, tidak ada jalan bagi manusia tidak taat kepada Tuhan. Salah satu contoh ketaatan kepada-Nya, yakni memelihara kejujurannya. Kejujurannya merupakan salah satu kriteria untuk menyatakan beriman tidaknya seseorang. Kejujuran akan tampak dalam bentuk nyata atau dalam bentuk tingkah laku apabila seseorang mempunyai hati yang bening. Pada dasarnya, manusia dapat dikatakan jujur apabila memenuhi tiga syarat, yaitu jujur kepada Tuhan, jujur kepada sesama manusia, dan jujur kepada diri sendiri. Jujur kepada Tuhan dapat dibuktikan melalui ketaatan menjalankan perintah dan menjauhi larangan-Nya. Jujur kepada sesama manusia artinya menghormati hak-hak orang lain. Jujur kepada diri sendiri, yakni adanya kemampuan untuk menanamkan nilai-nilai kebenaran dalam pribadi kita masing-masing.

Sebagai bukti ketaatan kepada Tuhan, sepantasnyalah manusia itu senantiasa berdoa dan bermohon hanya kepada Tuhan Yang Mahakuasa seperti yang tergambar dalam ungkapan (2) berikut.

\section{Langngan kibungkaq baqbana,} kitumbekmengguallina (Sande, 1994: 32) Artinya: Kami naik membuka pintu-Nya dan mengetuk daun jendela-Nya.

Maksudnya: Berdoa dan bermohon kepada Yang Mahakuasa.

Ungkapan tersebut melukiskan manusia yang selalu berharap serta menyandarkan diri kepada sang Penguasa yaitu Tuhan. Secara tersirat pula tergambar dalam ungkapan tersebut bahwa manusia menyadari dirinya memiliki keterbatasan dan berbagai kekurangan dibanding dengan kesempurnaan yang dimiliki oleh Tuhan. Memang diakui bahwa manusianyang tahu akan eksistensi dirinya sebagai makhluk hidup ciptaan-Nya akan senantiasa mendekatkan diri kepada Tuhan. Untuk mendekatkan diri kepada Tuhan diperlukan ibadat sebagai sarananya. Dengan beribadah, manusia dapat lebih mendekatkan diri dengan sang Pencipta yakni dengan jalan berdoa seraya bermohon kepada Tuhan yang merupakan satu-satunya tempat manusia berserah diri. Dengan doa manusia dapat bermohon harapan, permintaan, dan pujipujian kepada-Nya.

Orang yang senantiasa mendekatkan diri dengan memperbanyak doa dan permohonan kepada Tuhan seperti yang tergambar dalam ungkapan (2) tidak pernah merasa takut menghadapi kematian. Hal ini disebabkan karena mereka memiliki keyakinan bahwa dirinya adalah kepunyaan Tuhan. Simaklah ungkapan berikut.

\section{Tallang turanankiq Puangeoqbelaq- belaranna (Sande, 1994:107)}

Artinya: Kita ini bambu dan aur yang dibutuhkan Tuhan.

Maksudnya: Tidak perlu takut kepada kematian karena hidup kita kepunyaan Tuhan.

Ungkapan tersebut melukiskan manusia yang sepenuh hati berserah diri kepada Tuhan. Hal ini terbukti akan kebesaran jiwa seseorang menerima kematian itu sebagai suatu takdir yang telah ditentukan oleh Tuhan seperti yang 
tergambar dalam ungkapan (3). Ungkapan ini juga menggambarkan sikap manusia bijaksana yang tidak takut menghadapi kematian sebab mereka yakin bahwa manusia adalah kepunyaan Tuhan. Dengan keyakinan seperti ini berarti manusia tahu akan hakikat dirinya sebagai hamba Allah yang bila saatnya telah tiba, mereka akan kembali ke hadirat Allah melalui proses kematian. Kematian merupakan proses akhir kehidupan manusia di atas bumi ini. Tak satu pun makhluk hidup yang melata di atas bumi ini yang luput dari kematian. Sebagai makhluk hidup, manusia yang beriman seharusnya membekali diri dengan berbagai amal kebajikan untuk menghadapi kematian.

\section{Hubungan Manusia dengan Alam}

Hubungan manusia dengan alam merupakan salah satu hal yang mendasar dalam kehidupan manusia.Manusia tidak dapat memisahkan dirinya dengan alam. Dalam kehidupan nyata, manusia yang bersatu dengan alam mungkin tampak dalam diri manusia yang berupaya untuk hidup selaras dengan alam. Manusia yang menaklukkan dan mendayagunakan alam adalah manusia yang memanfaatkan alam untuk kehidupan manusia tanpa merusak alam, sedangkan manusia yang mensykuri alam pada umumnya memandang bahwa alam adalah karunia sekaligus cermin kebesaran Tuhan. Sementara itu, terdapat pula penggambaran citra manusia yang mengagumi kebesaran dan kedahsyatan alam.

Konsep hubungan manusia dengan alam dapat disimak dalam ungkapan Toraja sebagai berikut.

\section{Sitaranak kalopakna lipuq sanda} kaluaq(Sande, 1994:86).

Artinya: saling menunggu dengan negeri yang cukup luas.

Makudnya: Manusia yang mendiami muka bumi yang sangat luas ini.

Ungkapan tersebut menggambarkan manusia dalam hubungannya dengan alam ini. Tidak dapat dipungkiri bahwa hampir seluruh permukaan bumi yang sangat luas ini dihuni oleh manusia. Sebagai penghuni dan penguasa bumi ini, manusia mengambil banyak manfaat atas keberadaannya di atas permukaan bumi. Manfaat yang diperoleh, antara lain, yang bersumber dari alam itu sendiri dan yang bersumber dari sesama manusia. Manfaat yang diperoleh dari alam berupa berbagai sumber mineral dan pertanian, sedangkan manfaat yang diperoleh dari sesama manusia berupa kehidupan bermasyarakat yang diharapkan dapat menciptakan suasana hidup nyaman dan tenteram. Dengan manfaatmanfaat seperti itu, sepantasnyalah jika manusia senantiasa bersyukur dan berterima kasih kepada pencipta bumi ini. Bentuk terima kasih itu dilakukan dengan jalan melaksanakan segala perintahnya dan menjauhi larangan-Nya sesuai ajaran yang dianut oleh setiap manusia.

Sebagai penghuni bumi, tidak pantas kalau manusia itu menyia-nyiakan keberadaannya di atas bumi. Mereka dituntut serta diberi tanggung jawab untuk memelihara alam atau negeri ini seperti yang disinggung dalam ungkapan (5) berikut.

\section{Kambiq pantaqnakan lolo (Sande,} 1994:28)

Artinya: Selalu bersama dengan pesemaian sejati

Maksudnya: Dia yang memelihara negeri asal leluhur.

Ungkapan tersebut menggambarkan manusia yang senantiasa memelihara alam ini. Sebagai makhluk yang pandai bersyukur atas pemberian sang Pencipta, tidak sepantasnya manusia menelantarkan alam ini apalagi sampai merusak lingkungannya. Manusia seharusnya memelihara negeri ini dengan memanfaatkan sebaik-baiknya berbagai kekayaan alam yang telah diciptakan Tuhan untuk kemaslahatan umat manusia. Sebagai penduduk suatu negeri, manusia harus sadar untuk selalu membekali dirinya dengan menambah ilmu pengetahuan sebagai bekal untuk membangun negeri asal leluhurnya, baik pembangunan moril amupunmateril. Dengan cara seperti ini akan tercipta manusia 
yang memiliki rasa tanggung jawab yang tinggi terhadap pemeliharaan negeri ini sebagaimana yang tergambar dalam ungkapan tadi.

Jika manusia pandai memelihara alam atau negeri ini seperti yang digambarkan dalam ungkapan (5), dapat dipastikan bahwa segala sesuatu yang diinginkan oleh manusia mudah terpenuhi. Keadaan seperti inilah yang digambarkan dalam ungkapan berikut.

6. Lembang dipapai bayak, ditarampok kimataran (Sande, 1994:36).

Artinya: Perahu yang beratap parang diberi anak atap dengan senjata.

Maksudnya: Suatu negeri yang sudah lengkap.

Secara tersirat, ungkapan tersebut menggambarkan manusia yang mengakui dan mensyukuri keberadaan negeri yang sudah lengkap. Ungkapan pengakuan dan rasa syukur yang dimaksud di sini sudah tentu tidak hanya sebatas ucapan saja, tetapi diimplementasikan pula dalam sikap dan perbuatan nyata seperti yang dikemukakan dalam ungkapan terdahulu.

Kita ketahui bersama bahwa alam Toraja yang kaya akan potensi sumber alamnya berupa hasil pertanian sudah tentu memicu masyarakat yang mendiaminya untuk menjadi masyarakat agraris. Memang diakui bahwa masyarakat Toraja memiliki etos kerja yang tinggi yang diwariskan dari leluhur mereka. Selain sektor pertanian, masyarakat Toraja menggeluti pula sektor-sektor lain yang turut berperan dalam membangun negeri. Sektor-sektor tersebut sebagai penunjang pembangunan yang bertujuan untuk menyejahterahkan masyarakat.Hal ini sejalan dengan maksud ungkapan yang disebut di atas.

\section{Hubungan Manusia dengan Masyarakat}

Tidak mungkin manusia memisahkan diri dari kehidupan bermasyarakat. Di samping keterikatan manusia dengan masyarakat, manusia memiliki pula kepentingan-kepentingan pribadi, yang dapat saja selaras dan dapat pula berbenturan dengan kepentingan masyarakat. Oleh sebab itu, dalam hubungan ini biasanya muncul dua corak hubungan, yaitu keserasian atau keselarasan dan konflik. Hubungan manusia yang selaras dengan masyarakat, misalnya, akan melahirkan manusia yang cinta dan mengabdi pada tanah air atau manusia yang mengabdi pada keluarga sebagai bagian terkecil dari masyarakat. Sementara itu, konflik akan menampakkan manusia yang memberontak terhadap kemapanan atau tradisi yang ada dalam masyarakat atau manusia yang resah terhadap situasi masyarakat.

Konsep hubungan manusia dengan masyarakat dapat disimak dalam ungkapan Toraja sebagai berikut.

7. Umbangun biang raqba(Sande, 1994: 119)

Artinya: Membangun gelagah yang rebah. Maksudnya: Menolong masyarakat dalam menanggulangi musibah terutama dalam peperangan.

Secara tersirat ungkapan tersebut menyinggung manusia dalam hubungannya dengan masyarakat. Seperti yang diketahui bersama bahwa dampak yang timbul sebagai akibat peperangan adalah timbulnya berbagai macam musibah. Dalam ungkapan tadi tergambar dampak yang timbul akibat peperangan yang sangat dirasakan oleh masyarakat. Merupakan suatu tindakan yang arif dan bijaksana jika kita menolong masyarakat yang tertimpa musibah yang memang sangat memerlukan pertolongan. Bentuk pertolongan yang mereka harapkan tidak hanya terbatas pada bantuan-bantuan fisik saja, tetapi mereka memerlukan bantuan nonfisik. Dengan bantuan yang diberikan diharapkan untuk meringankan beban masyarakat yang tertimpa musibah peperangan.

Dampak yang ditimbulkan dari hasil peperangan memang membuat masyarakat menjadi sengsara. Namun, kesengsaraan itu sedikit akan terasa ringan jika ditanggulangi bersama, apalagi jika tampil seseorang pemimpin yang dapat bekerja sama denganmasyarakat. Figur pemimpin seperti itu tergambar dalam ungkapan berikut. 


\section{Paarrang tuntungan biaq (Sande,} 1994:67).

Artinya: Memasang sehingga bercahaya bagai obor.

Maksudnya: Pemimpin yang membawa terang.

Ungkapan tersebut menggambarkan manusia dalam hubungannya dengan masyarakat. Hal ini yang digambarkan dalam ungkapan (8) merupakan figur seorang pemimpin masa depan yang didambakan oleh masyarakat. Pemimpin yang membawa terang yang dimaksud dalam ungkapan ini adalah pemimpin yang dapat menciptakan suasana kondusif dalam berbagai sektor kehidupan. Suasana seperti itu hanya dapat tercipta jika seorang pemimpin memiliki kemauan dan kemampuan serta tanggung jawab yang tinggi dalam mengemban amanah yang dibebankan kepadanya. Pemimpin seperti itu, juga hendaknya memiliki wawasan yang luas. Dengan wawasan yang luas, ia dapat berbuat bijaksana dalam menyikapi semua permasalahan yang dihadapinya, baik yang datang dari dirinya sendiri, maupun yang datangnya dari orang lain atau orang yang dipimpinnya.

Pemimpin yang membawa terang seperti yang digambarkan dalam ungkapan (8) tidak hanya mampu menciptakan suasana kondusif, tetapi dia dapat pula menjadi pemimpin tumpuan harapan dan tempat bertanya. Hal ini dapat disimak dalam ungkapan berikut.

\section{Batu parandanganta sola nasang (Sande,} 1994:5).

Artinya: Batu sendi kita semua.

Maksudnya: Pemimpin tumpuan harapan dan tempat bertanya.

Ungkapan tersebut menggambarkan manusia dalam hubungannya dengan masyarakat. Pola relasi manusia yang memiliki jiwa pengabdian yang besar terhadap masyarakat dilakukan oleh seorang pemimpin yang menjadi tumpuan harapan serta tempat untuk menanyakan berbagai hal yang terjadi dalam masyarakat. Sebagai tumpuan harapan dan tempat bertanya, seorang pemimpin seharusnya perlu dibekali dengan wawasan yang luas. Wawasan ini merupakan modal dalam menjalankan roda kepemimpinannya. Dengan wawasan yang luas, seorang pemimpin akan mudah menemukan solusi atas berbagai masalah atau pertanyaan yang ditujukan kepadanya. Tipe pemimpin seperti inilah merupakan figur pemimpin yang diidam-idamkan oleh masyarakat sebagaimana yang disinggung dalam ungkapan tadi.

\section{Hubungan Manusia dengan Manusia Lain}

Di antara makhluk ciptaan Tuhan, manusia adalah makhluk yang paling sempurna penciptaannya di bumi ini. Namun, kesempuranaan itu tetap ada batasnya. Keterbatasan manusia, antara lain, manusia tidak dapat hidup tanpa kehadiran manusia lain. Di sisi lain, kehadiran manusia lain itu dapat menimbulkan masalah. Seorang manusia, selain mampu menjalin kerja sama dengan orang lain, dalam dirinya juga tersimpan potensi konflik dengan manusia lain. Oleh sebab itu, dalam hubungan manusia dengan manusia lain dapat dikatakan terdapat dua tipe yang mendasari, yaitu keselarasan/keserasian dan konflik.

Konsep hubungan manusia dengan manusia lain ini dapat disimak dalam ungkapan Toraja sebagai berikut.

\section{Aqrakana ladipa tobangrok olaqta napadangt upensa melona tau (Sande, 1994: 9).}

Artinya: Tidak mungkin dijatuhkan ke dalam retak tanah kebaikan hati seseorang.

Maksudnya: Budi baik orang lain kepada kita tidak boleh dilupakan walau dalam keadaan bagaimanapun.

Ungkapan tersebut menggambarkan manusia dalam hubungannya dengan manusia lain. Karakter manusia yang mengimbau kepada setiap orang agar budi baik seseorang tidak dilupakan begitu saja. Dalam melakukan berbagai aktivitasnya, manusia senantiasa berinteraksi dengan manusia lain. Dalam berinteraksi itu, manusia dituntut untuk menanamkan budi 
pekerti yang baik dalam dirinya masingmasing. Namun, tidak jarang pula ditemukan dalam masyarakat, ada manusia yang berbudi pekerti buruk. Barometer uuntuk mengukur baik buruknya budi pekerti seseorang adalah kemampuan seseorang untuk menanamkan nilai-nilai kebenaran dalam hidupnya. Orang yang berbudi pekerti yang buruk tentu banyak melakukan hal yang bertentangan dengan nilai kebenaran. Orang yang berbudi pekerti yang baik akan banyak berperilaku sesuai dengan nilai-nilai kebenaran seperti yang digambarkan dalam ungkapan (10).

Kalau ungkapan (10) merupakan gambaran manusia dalam hubungannya dengan manusia lain yang bernilai baik, ungkapan (11) berikut mengandung makna yang bernilai buruk.

11. Susibang totangunkan dema lassu (Sande, 1994: 85).

Artinya: Seperti orang yang tidak makan panas.

Maksudnya: Orang yang tidak pernah merasakan perasaan sesamanya manusia.

Ungkapan tersebut menggambarkan manusiadalamhubungannyadenganmanusialain. Kalau ungkapan sebelumnya menggambarkan manusia yang bernilai baik maka ungkapan ini menggambarkan manusia yang bernilai buruk. Gambaran sifat manusia yang dikemukakan dalam ungkapan ini merupakan salah satu perilaku manusia yang sangat tercela. Manusia seperti itu bertindak sesuai dengan keinginannya sendiri tanpa memandang perasaan orang lain. Sebagai makhluk sosial yang berbudaya, tidak sepantasnya manusia itu melakukan tindakan sewenang-wenang yang dapat melukai perasaan sesama manusia. Manusia harus senantiasa memelihara hubungan baik sehingga tercipta rasa tenteram dalam masyarakat. Memang diakui bahwa memulihkan perasaan orang yang sudah terluka bukanlah hal yang mudah sebab diperlukan waktu yang lama.

Relasi manusia terhadap manusia lain yang juga bermakna buruk dapat disimak dalam ungkapan berikut.
12. Ussussuq talluna (Sande, 1994: 129). Artinya: Mengisap telurnya.

Maksudnya: Mencabuli anak atau kemanakan sendiri.

Ungkapan tersebut menggambarkan manusia dalam hubungannya dengan manusia lain. Perilaku manusia seperti yang digambarkan dalam ungkapan (12) adalah perilaku yang sangat tercela. Sebagai manusia yang berbudaya dan beragama, manusia Toraja pantang melakukan perbuatan tercela seperti mencabuli anak atau kemanakan sendiri. Perbuatan seperti itu merupakan perbuatan biadab, perbuatan amoral yang tidak pantas dilakukan oleh manusia yang berbudaya. Manusia yang melakukan perbuatan seperti itu pantas untuk mendapatkan sanksi hukum yang berat serta sanksi dari masyarakat berupa pengucilan, dan yang lebih berat lagi adalah sanksi moral yang akan membebani hidupnya. Hal ini dilakukan sebab mencabuli seseorang merupakan perbuatan yangdilarang dalam agama, apalagi mencabuli anak atau kemanakan sendiri yang dalam silsilah keturunan masih termasuk kerabat dekat.

\section{Hubungan Manusia dengan Diri Sendiri}

Padasaat-saattertentu,manusiaberhadapan dengan diri sendiri. Dalam berhadapan dengan diri sendiri, kemungkinan ia berhadapan dengan berbagai masalah, baik yang berasal dari luar maupun dari dalam dirinya. Semua masalah yang dihadapinya itu menjadi bahan perenungan bagi dirinya, yang barangkali akan melahirkan suatu pengendapan, dan mungkin pula suatu konflik batin. Konsep hubungan manusia dengan dirinya sendiri dapat disimak dalam ungkapan Toraja sebagai berikut.

13. Aku tali-tali tallang, aku songkoq peladaran (Sande, 1994: 2)

Artinya: Aku ini tali bambu, topi pelajaran.

Maksudnya: Saat ini perlu banyak belajar karena masih anak-anak.

Ungkapan tersebut menggambarkan manusia dalam hubungannya dengan diri sendiri. 
Hal yang digambarkan dalam ungkapan tersebut merupakan kontemplasi yang muncul dari diri seseorang. Ini dilakukan bagi orang yang sadar akan pentingnya mengisi hidup ini dengan berbagai macam kegiatan yang bermanfaat yang salah satu diantaranya adalah belajar. Belajar adalah usaha untuk memperoleh kepandaian atau ilmu. Memang diakui bahwa dengan belajar, manusia akan mendapatkan banyak tambahan ilmu pengetahuan yang merupajan modal dasar dalam menjalani hidup ini. Dengan ilmu, manusia memiliki kemampuan manajerial yang tinggi sehingga setiap permasalahan mudah diatasi. Namun, perlu diketahui bahwa manusia tidak cukup hanya dengan bekal ilmu, tetapi perlu pula dibekali dengan agama. Jika ilmu lebih dominan menguasai seseorang, akan jadilah manusia itu sebagai manusia yang sekuler. Apa yang digambarkan dalam ungkapan tadi adalah sikap yang sangat tepat sebab memang idealnya manusia itu harus mulai belajar sejak masih muda.

Dengan berbekal ilmu yang diperoleh sejak masih muda seperti yang disinggung dalam ungkapan (13), manusia akan banyak menemui kemudahan dalam menjalani hidupnya. Dengan ilmu itu pula, manusia akan senantiasa berpikir bijak dalam menghadapi berbagai macam tantangan hidup ini. Gambaran manusia seperti itu dapat disimak sebagai berikut.

\section{Makarraq tuo (Sande, 1994: 51)}

Artinya: keras hidup

Maksudnya: Hidup tabah menghadapi segala penderitaan.

Ungkapan tersebut menggambarkan manusia dalam hubungannya dengan diri sendiri. Manusia dalam menjalani hidupnya sering diperhadapkan dengan berbagai masalah, baik yang berasal dari luar maupun dari dalam dirinya sendiri. Hal yang digambarkan dalam ungkapan ini merupakan salah satu tantangan yang haru dihadapi dalam hidup ini. Perjalanan hidup ini silih berganti, kaadang-kadang orang merasakan perjalanan hidupnya selalu tenteram, dan saat tertentu manusia mengalami penderitaan. Tipe manusia seperti yang digambarkan dalam ungkapan ini adalah tipe manusia yang tabah menghadapi berbagai penderitaan. Manusia seperti ini biasanya memikiki kemampuan untuk mengendalikan dirinya sehingga cobaan apa pun yang menerpa dirinya, ia tetap menerima dengan hati yang sabar.

Selain ungkapan (13) dan (14), ungkapan (15) menggambarkan pula manusia dalam hubungan dengan dirinya sendiri. Simaklah sebagai berikut.

\section{Umpassatang panglembana (Sande,} 1994: 119).

Artinya: Memikul atau membawa sesuatu yang bukan bawaannya.

Maksudnya: Memaksa diri yang tidak disanggupi

Ungkapan tersebut menyinggung tentang manusia dalam hubungannya deangan diri sendiri.Sikap manusia seperti yang disinggung dalam ungkapan (15) merupakan suatu tindakan nekat yang dapat beresiko. Namun, resiko ini kadang-kadang diabaikan jika keadaan sudah memaksa.Berbagai hal yang dapat membuat manusia bersikap seperti itu. Dalam kehidupan ini, biasanya manusia diperhadapkan pada berbagai masalah, baik masalah yang ringan maupun masalah yang berat. Masalah yang ringan dapat terselesaikan tanpa harus memaksakan diri. Namun, jika manusia menemui masalah yang berat, terkadang manusia memaksa diri untuk melakukan berbagai hal yang sudah diluar kesanggupannya. Tidak hanya dalam persoalan-persoalan yang berat manusia itu memaksa diri, tetapi tidak jarang pula kita dapati manusia memaksa diri karena didorong oleh keinginan untuk memperoleh sesuatu di luar kesanggupannya. Keadaan seperti ini yang harus disikapi secara arif sebab jika arif menyikapinya, dapat diyakini akan membuat manusia hidup dalam kesengsaraan yang berkepanjangan.

\section{PENUTUP}

Ragam relasi manusia dalam ungkapan Toraja, dapat disimpulkan sebagai berikut. 
Dalam hubungan manusia dengan Tuhan tampak pribadi manusia dengan ketakwaan yang sangat kuat. Ketakwaan itu tampak dalam gambaran manusia yang taat kepada Tuhan dengan banyak berdoa memohon kepada-Nya. Jika dalam ungkapan Toraja yang mengemukakan masalah hubungan manusia dengan Tuhan sama sekali tidak ditemukan corak pengingkaran, itu bukan berarti kualitas religius manusia yang terungkap dalam ungkapan Toraja sudah dapat dibanggakan. Tentu diketahui bersama bahwa disamping citra manusia yang takwa, pasti ada pula citra manusia yang ingkar. Hanya saja, dalam data ini belum ditemukan ungkapan yang menggambarkan manusia yang ingkar.

Dalam hubungan manusia dengan alam, ungkapan Toraja lebih banyak menyinggung tentang corak pendayagunaan alam yang di dalamnya sudah tersedia berbagai sumber kehidupan. Sehubungan dengan itu, manusia sadar akan keberadaannya sehingga senantiasa mensyukuri keberadaan alam ini dengan cara memelihara alam.

Sesuai dengan kehidupan masyarakat Toraja yang berjiwa sosial, ungkapan Toraja yang memunculkan manusia dalam hubungannya dengan masyarakat lebih banyak mengarah pada penciptaan kehidupan kemasyarakatan yang lebih baik. Hal ini terbukti dengan adanya kerja sama yang baik antara pemerintah atau pemimpin dengan orang yang dipimpinnya.

Ungkapan Toraja yang mengemukakan manusia dalam hubungannya dengan manusia lain ternyata memunculkan dua tipe manusia, yakni tipe manusia yang lebih mencari keselarasan dan tipe manusia yang kadangkadang menciptakan konflik.

Dalam hubungan manusia dengan dirinya sendiri tergambar karakter manusia yang banyak berkontemplasi. Hal ini kadang-kadang melahirkan suatu pengendapan dan mungkin pula suatu konflik batin.

\section{DAFTAR PU(STAKA}

Djajasudarma, T. Fatimah. (1997), Nilai Budaya dalam Ungkapan dan Peribahasa Sunda. Jakarta: Pusat pembinaan dan Pengembangan bahasa, Departemen Pendidikan dan Kebudayaan.

Damono, Supardi Djaka. (2000), Sosiologi Sastra. Jakarta: Pusat Pembinaan dan Pengembangan Bahasa.

Farouk, (2005), Pengantar Sosiologi Sastra. Jogyakarta: Pustaka Pelajar.

Kobong, Theo 1983), Manusia Toraja. Tangmentoe: Institut Theologia Gereja Toraja.

Koentjaraningrat. (1988), Manusia dan Kebudayaan Indonesia. Jakarta: Penerbit Djambatan.

Ratna, Nyoman Kutha, (2003), Paradigma Sosiologi Sastra. Jogjakarta: Pustaka Pelajar.

Rijal, Syamsul. (1999), Nilai Budaya dalam Ungkapan Toraja. Jurnal Sawerigading (hlm. 123-146) No. 10, Juni 1999. Ujung Pandang: Balai Bahasa.

Sande, J.S. (1994), Ungkapan dan Peribahasa dalam Sastra Toraja. Jakarta: Pusat pembinaan dan Pengembangan Bahasa, Departemen Pendidikan dan Kebudayaan.

Sumarjo, Jakob. Jakarta (1979), Masyarakat dan Sastra Indonesia. Yogyakarta: CV. Nur Cahaya.

Suwonda, Tirto. (2003), Studi Sastra: Beberapa Alternatif. Yogyakarta: PT. Hamita Graha Wijaya.

Teeuw, A. (1991), Membaca dan Menilai Sastra. Jakarta. PT Gramedia Pustaka Utama.

Tim Penyusun Kamus Pusat Pembinaan dan Pengembangan Bahasa. (2008), Kamus Besar Bahasa Indonesia (Edisi Ketiga). Jakarta: Balai Pustaka. 